\title{
Pharmacological activity and biochemical interaction of zingerone: a flavour additive in spice food
}

\author{
Bhaskar Chandra Sahoo, Suprava Sahoo*, Sanghamitra Nayak \& Basudeba Kar* \\ Centre for Biotechnology, Siksha ‘O’ Anusandhan deemed to be University, Bhubaneswar, Odisha, India, 751003 \\ *Email: basu.cbt@gmail.com, supi.sos2000@gmail.com
}

OPEN ACCESS

\section{ARTICLE HISTORY}

Received: 21 January 2021

Accepted: 13 June 2021

Available online

Version 1.0 (Early Access): 20 November 2021

Version $2.0: 01$ January 2022

\section{Check for updates}

\section{Additional information}

Peer review: Publisher thanks Sectional Editor and the other anonymous reviewers for their contribution to the peer review of this work.

Reprints \& permissions information is available at https://horizonepublishing.com/ journals/index.php/PST/open_access_policy

Publisher's Note: Horizon e-Publishing Group remains neutral with regard to jurisdictional claims in published maps and institutional affiliations.

Indexing: Plant Science Today, published by Horizon e-Publishing Group, is covered by Scopus, Web of Science, BIOSIS Previews, Clarivate Analytics, etc. See https:// horizonepublishing.com/journals/index.php/ PST/indexing_abstracting

Copyright: $(\subset)$ The Author(s). This is an openaccess article distributed under the terms of the Creative Commons Attribution License, which permits unrestricted use, distribution and reproduction in any medium, provided the original author and source are credited (https://creativecommons.org/licenses/ by/4.0/)

\section{CITE THIS ARTICLE}

Sahoo B C, Sahoo S, Sanghamitra Nayak S, Kar B. Thermal treatments affected to quality attributes of Solanum procumbens Lour. Plant Science Today. 2022;9(1):81-88. https:// doi.org/10.14719/pst.1102

\begin{abstract}
Zingerone (4-(4-Hydroxy-3-methoxyphenyl)-2-butanone) is one of the nonvolatile and nontoxic compounds of ginger. It is also called vanillylacetone with a crystalline solid form which is sparingly soluble in water and more soluble in ether. The contribution of this compound in ginger is about $9.25 \%$. The chemical structure is made of a phenolic ring with methoxy group attached to benzene ring. Gingerol can be heated to form zingerone by retroaldol reaction. It has been reported that zingerone has multiple pharmacological activities. It is effective against diarrhoea causing enterotoxigenic bacteria that leads to infant death. It is also used against intestinal gastric, oxidative stress, weak immunity, obesity. During its activity against cancer, it governs the expression of different cell cycle protein and TGF- $\beta 1$ expression. Antioxidant response is controlled by inducing the activity of ROS neutralising enzymes like superoxide dismutase, catalase and glutathione reductase. It can also reduce various inflammations by restricting the activity of interleukins. This review summarizes the multiple pharmacology activities of zingerone against various important diseases like cancers, tumors, inflammations, oxidative conditions, microbial infections, biofilm formations, thrombosis and other diseases. In addition, the molecular regulation of these pharmacological responses by zingerone is also critically discussed.
\end{abstract}

\section{Keywords \\ anticancer, anti-inflammation, antioxidant, ginger, zingerone}

\section{Introduction}

Ginger (Zingiber officinale Roscoe) is well known for its medicinal properties and its use in spices. It contains various minerals and vitamins which are the basic need of human diet. Ginger is a traditional medicine, having immense active ingredients used for the treatment of numerous diseases ( 1 , 2). Ginger has antidiabetic, anti-inflammatory, anticancer, analgesic, hepatoprotective efficacy (3). According to the literature, more than 60 active volatile and non-volatile compounds have already been reported in leaves and rhizome of ginger. The major volatile components found in rhizome essential oil of ginger are zingiberene, curcumene and farnesene bsesquiphellandrene $(4,5)$. The non-volatile compounds present in the rhizome of $Z$. officinale are gingerols, shogaols, paradols and zingerone (4-6). The contribution of zingerone in ginger is about $9.25 \%$ (2). Zingerone is also found in the floral parts of Bulbophyllum sp. like Bulbophyllum patens and $B$. baileyi $(7,8)$. In $B$. patens, zingerone was found to be highest that is $930 \mathrm{ppm}$ 
in the labellum while other parts like sepals, petals and column were having 167 ppm, 95 ppm, 51 ppm respectively (7).

However, zingerone is an important medicinal active compound and is predominantly found in ginger. It bears a strong, spicy, pungent odour reminiscent of ginger (9). It also known as vanillylacetone and its IUPAC name is 4-(4-hydroxy-3-methoxyphenyl)-2-butanone $\left(\mathrm{C}_{11} \mathrm{H}_{14} \mathrm{O}_{3}\right)(10)$ (Fig. 1). It is a non-volatile constituent which is naturally

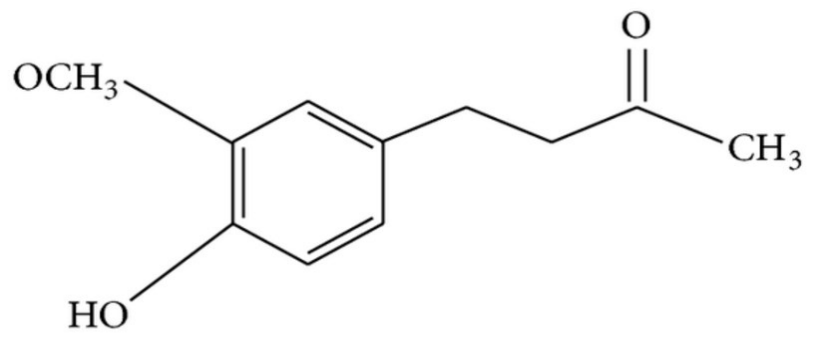

Fig. 1. Chemical structure of zingerone

produced directly during drying of ginger and also indirectly by thermal degradation of gingerols or shogaols (2). Gingerol is heated to produce zingerone and aldehyde in retro aldol reaction (Fig. 2). In addition, zingerone is an phenylquinolin-3-yl) methyl)-2-methoxyphenol were synthesized (15).

In 2017, the total global burden of health was more than 2.4 billion (16). This includes more than 362 million of cardiovascular diseased patients, 230 million of cancer diseases, 133 million of diabetes and endocrine diseases, 84 million of digestive diseases and 40 million of liver diseases (16). However, these non-communicable diseases contribute more than 1.4 billion to the global health burden (16). Although several synthetic drugs are available against these diseases, herbal medicines are very effective without any side effect. Zingerone is a non-volatile constituent of ginger and is found to be a promising herbal medicine against multiple health disorders (17) (Fig. 3, Table 1). Zingerone treatment can reduce cancer, tumor, inflammation, cardiac diseases, thrombosis, obesity, diabetes and many other diseases (17-22). It also plays important role against platelet aggregation in blood (22). In cancer, use of this active compound can inhibit the expression of transforming growth factor-beta 1 (TGF- $\beta 1$ ) to control the cancer metastasis. It also regulates the $\mathrm{Bax}, \mathrm{Bcl} 2$ and cyclin d proteins to manage cancer diseases. During antiinflammatory activities, nuclear factor-kB (NF-kB) expression regulated by zingerone and the activities of interleu-

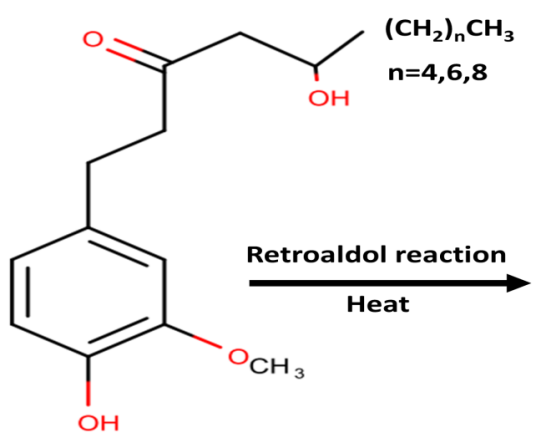

Gingerol

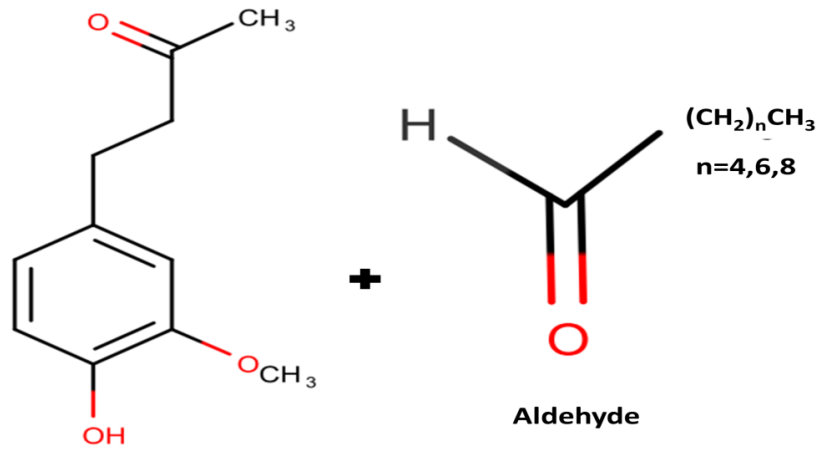

Zingerone

Fig. 2. Conversion of gingerol to zingerone.

important compound present in ginger oleoresin and it is very difficult to extract. However, few extraction methods are developed to extract this compound from ginger oleoresin. In a study, it was identified as major compound in ethanol extraction of ginger oleoresin by using ultrasound at a frequency of $42 \mathrm{kHz}$ and at a temperature of $60^{\circ} \mathrm{C}$ (11). In another study, the supercritical $\mathrm{CO}_{2}$ extraction method was optimized to $25 \mathrm{MPa}$ pressure, $45^{\circ} \mathrm{C}$ temperature and 150 min time for extraction of zingerone in ginger oleoresin (12). This compound can also be synthesized artificially $(13,14)$. Initially, under basic conditions both vanillin and acetone are allowed for aldol condensation to form dehydrozingerone. Then the dehydrozingerone is hydrogenated to form zingerone (14). In addition, five quinoline derivatives of zingerone such as 4-((2,4-Dimethylquinolin-3 -yl) methyl)-2-methoxyphenol, 2-Methoxy-4-((2-methyl-4phenylquinolin-3-yl) methyl)phenol, 2-Methoxy-4-((2methyl-6-nitro-4-phenylquinolin-3-yl) methyl)phenol, 4-((6 -Chloro-2-methyl-4-phenylquinolin-3-yl) methyl)-2methoxyphenol and 4-((6-Amino-2-methyl-4- kins are also reduced. Apoptosis also gets inhibited by use of this compound which regulates the caspases enzyme activities. It has also high antioxidant properties and induce the activity of ROS scavenging enzymes to control ROS production during stress (21). It has been also reported that zingerone treatment can reduce colon cancer and hepatocellular cancer and also effective against tumors by inhibiting cell cycle proteins (23-25). Several important pharmacological activities like anticancer, antitumor, antioxidant, anti-inflammatory of zingerone are discussed in this review.

\section{Biological importance}

As zingerone is one the important compound of ginger, it retains various types of medicinal and pharmacological properties. Zingerone is also a nontoxic compound. It has no side effects and is obtained from natural sources.

\section{Anticancer and Antitumor activities}

Zingerone derived from ginger has anticancer properties against colon cancer, hepatocellular carcinoma and tumor 


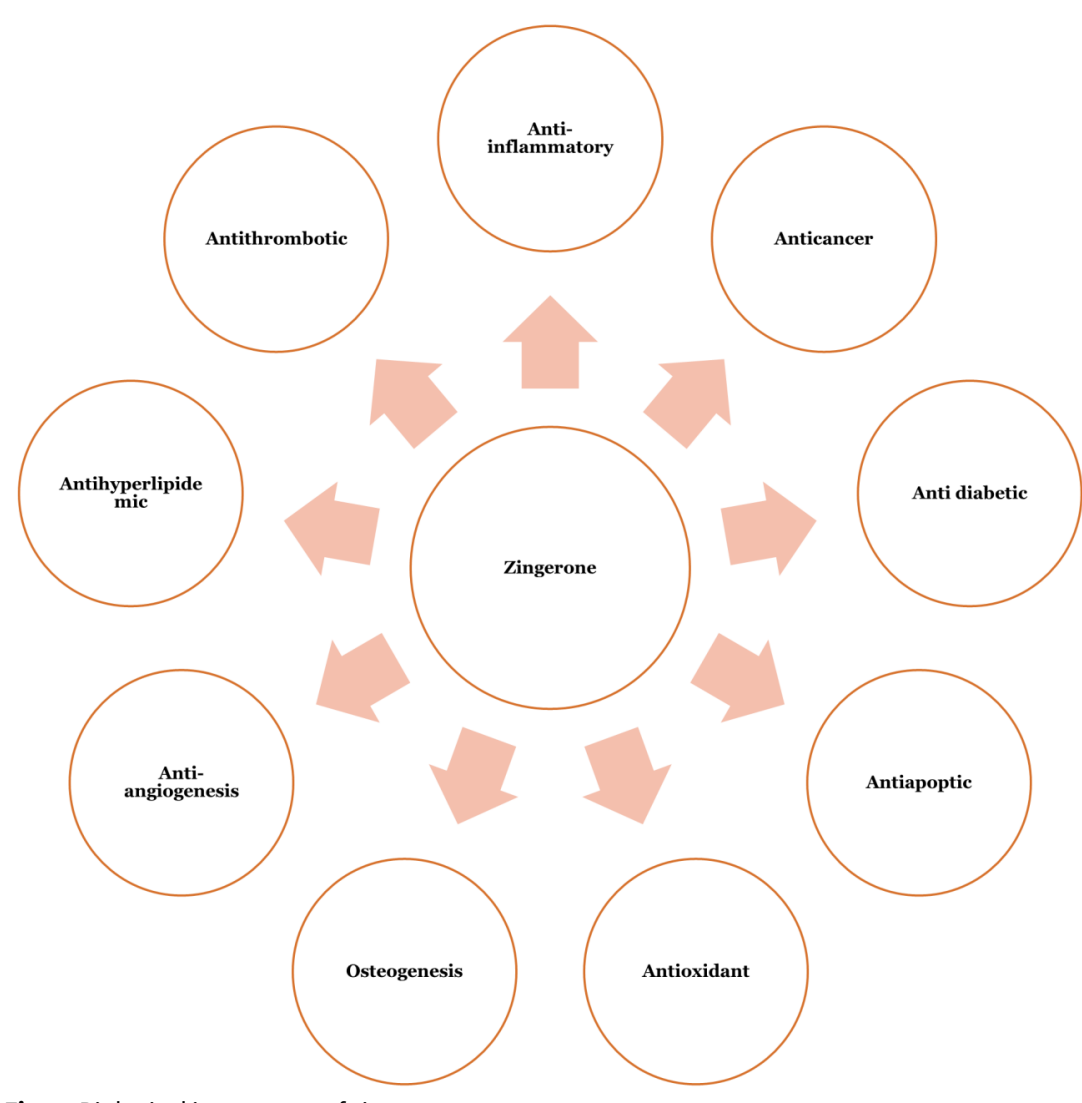

Fig. 3. Biological importance of zingerone

development $(20,23,25) .2 \mathrm{mM}$ of zingerone dissolved with dimethyl sulfoxide (DMSO) prevents the rapid divisions of cancer cells by inhibiting the expression of cyclin D1 (24). Cyclin D1 is a cell cycle check point protein, required at G1 phase of cell cycle. The $\mathrm{G} 1$ phase components undergo $\mathrm{S}$ phase, $\mathrm{G} 2$ phase and $M$ phase to complete a cell division (Fig. 4). Cyclin-dependent kinase (CDK) inhibitor p21 inhibits the cell cycle protein complexes like cyclin-cdk2, cdk1, cdk4/6 and stops cell cycle at S and G1 phase during Ultraviolet $B$ (UVB) induce cell damage. However, $40 \mathrm{mg} / \mathrm{kg}$ of this compound has the capacity to reduce the production of p21 and allow the cell to complete cell cycle during division (25). The derivative of this compounds is found effective against hepatocellular carcinoma (HCC) and its metastasis as well as found to act on TGF- $\beta 1$, which regulates epithelial mesenchymal transition (EMT) for metastasis (Fig. 4) of HCC (18). Further, its nanoparticles $(10 \mathrm{mg} / \mathrm{kg}$ ) have efficiency to reduce cell proliferation in tumor cells and enhance the pharmacological properties of the compound (26). In cancer cells, the zingerone nanoparticles increase DNA damage, which subsequently leads cancer cells to apoptosis. It acts over hepatocellular cancer cells and lead them to apoptosis by cascades of caspase signalling pathways. Caspase 3 activity is induced by this compound and it cleaves poly (ADP-ribose) polymerase (PARP) which is mainly responsible for death of cancer cells (24, 26). The effect of zingerone $(40 \mathrm{mg} / \mathrm{kg})$ against chemical induced colon cancer is tested in rat model (25). The colon cancer is reduced by inhibiting the formation of aberrant crypt foci (ACF) in colon tissue (25). ACF are abnormal tubular glands reside in the colon and rectum, which further leads to colon cancer (27). Tumor development is controlled by angiogenesis and this compound is also found effective against tumor angiogenesis. Matrix metalloproteinases (MMPs) are required for degradation of basement membrane during angiogenesis. The tumor cells treated with zingerone further retire angiogenesis by decreasing the MMP-2 and MMP-9 activities (20).

\section{Antioxidant activities}

Zingerone has an efficient role against reactive oxygen species (ROS), peroxides and free radicals. The antioxidant activities generally inhibit xanthine oxidase activity as xanthine oxidase is recruited ROS production (17). The ROS includes singlet oxygen $\left({ }^{1} \mathrm{O}_{2}\right)$, hydroxyl radical $\left({ }^{\circ} \mathrm{OH}\right)$, superoxide anion $\left(\mathrm{O}_{2}^{-}\right)$, hydroxyperoxyl $\left(\mathrm{HO}_{2}^{\circ}\right)$, peroxyl (ROO*), alkoxyl (RO*), ozone $\left(\mathrm{O}_{3}\right)$, hypochlorous acid $(\mathrm{HOCl})$, peroxynitrite $\left(\mathrm{ONOO}^{-}\right)$, hydrogen peroxide $\left(\mathrm{H}_{2} \mathrm{O}_{2}\right)$ (28). It triggers the activity of ROS detoxifying enzymes like superoxide dismutase (SOD), catalase (CAT), glutathione (GSH), glutathione reductase (GR) and glutathione peroxidase (GPX) (17-19). Structurally zingerone contains hydroxyl groups in the aromatic rings and double bonds between $\mathrm{C}_{3}$ and $\mathrm{C}_{4}$ carbon (29). This may support the antioxidant properties of zingerone. Alloxan is an organic compound induce diabetes by destroying insulin producing beta cells in pancreas and also produce ROS simultaneously. Zingerone is found effective to reduce the ROS level produced by alloxan by increasing the activities of SOD, CAT, GSH and GPx as compare to untreated diabetic rats (30). In exposure to radiations, various ROS products are also generated which can be controlled by zingerone (31). Zingerone is known to produce more numbers of scavenging enzymes when treated to radiation exposed cells. Apoptosis can be prevented by the application of zingerone. Two important proteins $\mathrm{Bcl}-2$ and Bax crosstalk play important role in regulation of apoptosis. Bcl-2 is an anti apoptic protein and Bax is a pro apoptic protein. Bax protein gets activated in response to ROS production and leads to apoptosis. However, application of zingerone increases the efficiency of Bcl-2 which subsequently acts over Bax (Fig. 4) and inhibit apoptosis (29). An elevated amount of ROS is produced during ischemia-reperfusion injury in neuron mitochondrial cells. This leads to apoptosis of neuron cells by involving intrinsic pathway of programmed cell death (iPCD) $(29,32)$. The application of zingerone (50 mg and 100 $\mathrm{mg} / \mathrm{kg}$ ) also lower the expression of Apaf -1 and Bax proteins in the neural cell during ischemia-reperfusion injury (32). Nitrite and peroxynitrite anions are nitrogen reactive compounds formed during oxidative stress. These are the product of reaction between nitric oxide (NO) and oxygen. By the use of zingerone $(25 \mu \mathrm{g} / \mathrm{ml})$ it competes with oxygen and is attached to NO to prevent the formation of nitrogen reactive compounds (29). Cisplatin is a compound used in chemotherapy, produces various types side effects. Cisplatin treated organisms mainly suffer from nephrotoxicity 
Table 1. Biological activities of Zingerone

\begin{tabular}{|c|c|c|c|c|}
\hline $\begin{array}{l}\text { Sl. } \\
\text { No. }\end{array}$ & Biological activities & Sample/organism & Effective amount of Zingerone & References \\
\hline 1. & $\begin{array}{l}\text { Anticancer, Antioxidant, Anti- } \\
\text { hyperproliferative }\end{array}$ & Rat (Colon) & $100 \mathrm{mg} / \mathrm{kg}$ & $(23)$ \\
\hline 2. & Anticancer & Human (Neuroblastoma cells) & 2 mM (Dissolved with dimethyl sulfoxide) & $(24)$ \\
\hline 3. & Antitumor & Mouse (Renca cells) & $10 \mathrm{mg} / \mathrm{kg}$ & (26) \\
\hline 4. & Antitumor & Human (Hepatoma cells) & $\begin{array}{l}50 \mathrm{uM} \text { (nano sized }(1.4 \mathrm{~nm}) \text { ) (Dissolved with } \\
\text { ethanol) }\end{array}$ & $(26)$ \\
\hline 6. & Anti-inflammation & Rat & $200 \mathrm{mg} / \mathrm{kg}$ & $(52)$ \\
\hline 7. & Anti-inflammation & Rat (Liver) & $100 \mathrm{mg} / \mathrm{kg}$ & (53) \\
\hline 8. & Anti-inflammation, Anti-fibrotic & Rat (Liver) & $20 \mathrm{mg} / \mathrm{kg}$ & (54) \\
\hline 9. & $\begin{array}{l}\text { Anti-inflammation, Antioxidant, Anti- } \\
\text { hyperlipidemic }\end{array}$ & Rat (Hepatic cells) & $20 \mathrm{mg} / \mathrm{kg}$ & (19) \\
\hline 10. & Anti-inflammation & Rat (kidneys) & $8 \mathrm{mg} / \mathrm{kg}$ & (44) \\
\hline 12. & Anti-inflammation & Mouse & $0.72 \mathrm{mg} / \mathrm{kg}$ & $(36)$ \\
\hline 13. & Anti-inflammation & Mouse (Colon) & $100 \mathrm{mg} / \mathrm{kg}$ & $(42)$ \\
\hline 14. & $\begin{array}{l}\text { Anti-inflammation, Antioxidant, } \\
\text { Antiapoptic }\end{array}$ & Rat & $25 \mathrm{mg} / \mathrm{kg}$ & (55) \\
\hline 15. & $\begin{array}{l}\text { Antioxidant, Antihyperlipidemic, } \\
\text { Antithrombotic }\end{array}$ & Rat (Heart) & $6 \mathrm{mg} / \mathrm{kg}$ & $(48,49)$ \\
\hline 16. & Antioxidant, Anticancer & Rat (Colon) & $40 \mathrm{mg} / \mathrm{kg}$ & $(25)$ \\
\hline 17. & Anti-Fxa and Anti platelet & $\begin{array}{l}\text { Human (Umbilical vein endothelial } \\
\text { cells) }\end{array}$ & 50 uM (Dissolved with dimethyl sulfoxide) & $(22)$ \\
\hline 18. & Antiapoptic & Rat (Heart) & $6 \mathrm{mg} / \mathrm{kg}$ & $(50)$ \\
\hline 19. & Antiangiogenic & Mouse (Renca cells) & $20 \mathrm{mg} / \mathrm{kg}$ & $(20)$ \\
\hline 20 & Antiapoptic & Human (Lymphocytes) & $10 \mathrm{ug} / \mathrm{ml}$ & $(31)$ \\
\hline 21 & Antioxidant & Human (Lymphocytes) & $10 \mathrm{ug} / \mathrm{ml}$ (treatment for more than $1 \mathrm{hr}$ ) & $(31)$ \\
\hline
\end{tabular}

disease, which reduces the antioxidant enzymes and in- matory cytokines in living organisms. Lipopolysaccharides creases malondialdehyde (MDA) production by lipid peroxi- induced acute systemic inflammation is controlled by dation. Zingerone in an amount of $50 \mathrm{mg} / \mathrm{kg}$ restores the zingerone. Zingerone reduce the production of $\mathrm{p} 65$ proteins activity of CAT and GPx. It also reduces MDA production in the cells which suffer from acute systemic inflammation (33). Zingerone $(500 \mathrm{ug} / \mathrm{ml})$ showed its protective effect $(40)$. P65 protein is attached with p50 protein to form a proagainst in vitro DNA damage induced by stannous chloride tein dimer in NF-KB signalling pathway. This protein dimer (34). Streptozotocin/high fat diet (STZ/HFD) causes type-2 is transferred to nucleus from cytosol after the proteosomal diabetes and increase ROS production in Wistar rat. ROS degradation of phosphorylated IkBa, which subsequently level decrease by zingerone as antioxidant enzymes in- initiate transcription of proinflammatory cytokines to show crease their own activities (35). Ethanol, the so-called alco- inflammation (41). Inflammatory bowel disease (IBD) is one hol can increase ROS production in living cells by reducing the important cause of colitis. NF-KB and IL- $1 \beta$ are imthe scavenging enzyme activities (19).

\section{Anti-inflammatory activities}

Proinflammatory cytokines such as interleukins (IL1-b, IL-6, IL-2) and tumor necrosis factor alpha (TNF- $\alpha$ ) are increased during chemical induced diabetes. IL1-b, IL-6, IL-2 and TNF$\alpha$ have an important role in malfunctioning the $\beta$ cells of pancreas during diabetes (30). These inflammatory cytokines are found to decrease in diabetes rats by the treatment of zingerone. It is in amount of $50 \mathrm{mg} / \mathrm{kg}$ successfully reduced the cisplatin induced inflammation by limiting TNF - a production (Fig. 4) in Wistar rats (33). UVB is very harmful radiation mainly responsible for epithelial cell damage and show inflammation by increasing the level of cytokines in keratinocyte stem cells (KSCs) (36). During UVB exposure, the elevated TNF- $\alpha$ employs inflammatory cells which secrete elastases and collagenases. They further lead to aging or skin damage (36-39). NF-kB pathway is one of the important signalling pathways to show inflammation by the cell under stress. Lipopolysaccharides produce proinflamportant proteins expressed during 2,4,6-trinitrobenzene sulphonic acid (TNBS) induced colitis. The microarray study for gene expression showed that ginger and zingerone (100 $\mathrm{mg} / \mathrm{kg}$ ) application reduce the expression of NF-KB and IL$1 \beta$ in TNBS induced colitis (42). Ethanol consumption also shows inflammatory response in hepatic cells through NF$\mathrm{KB}$ and leads to hepatoxicity. Zingerone $(20 \mathrm{mg} / \mathrm{kg})$ treatment increase the number of anti-inflammatory Nrf-2 (basic leucine zipper (bZIP) protein) protein and decrease NF-kB expression which reflects reduction in hepatotoxicity by zingerone (19). The probable mechanism behind zingerone $(100 \mathrm{mg} / \mathrm{kg})$ mediated anti-inflammatory therapy is inhibition of inflammatory genes expression like toll like receptor 4 (TLR4), RelA, NF-kB2, TNF- $\alpha$, iNOS, COX-2 (43). Peroxisome proliferator-activated receptors (PPARs) is associated with various types of biological activities like increasing cell proliferation, glucose and lipid metabolism, insulin sensitivity, tissue remodelling and inflammations. PPARs activities is increased by zingerone $(8 \mathrm{mg} / \mathrm{kg})$, which further supress NF-kB and prevent inflammation (44). 


\section{Antilipidemic activities}

Alcohol was also involved to increase lipids like cholesterol, triglycerides, free fatty acids, phospholipids and lowdensity lipoproteins. Zingerone has an emerging role in antihyperlipidemic and antiapoptotic properties (45). The elevated expression of TNF-a and IL-6 is reduced by zingerone. Triglyceride and cholesterol levels are decreased by zingerone. Nicotinamide adenine dinucleotide osteogenesis and boosted by zingerone in the mesenchymal stem cells. mRNA Runx2, involved differentiation is enhanced by zingerone treatment. Zingerone may deposit calcium, which is responsible for osteogenesis (51).

Apart from this, zingerone has also the efficiency to act as antithrombosis agent. Thrombosis generally takes place by conversion of FX to FXa, which further converts prothrombin to thrombin and sequentially again converts

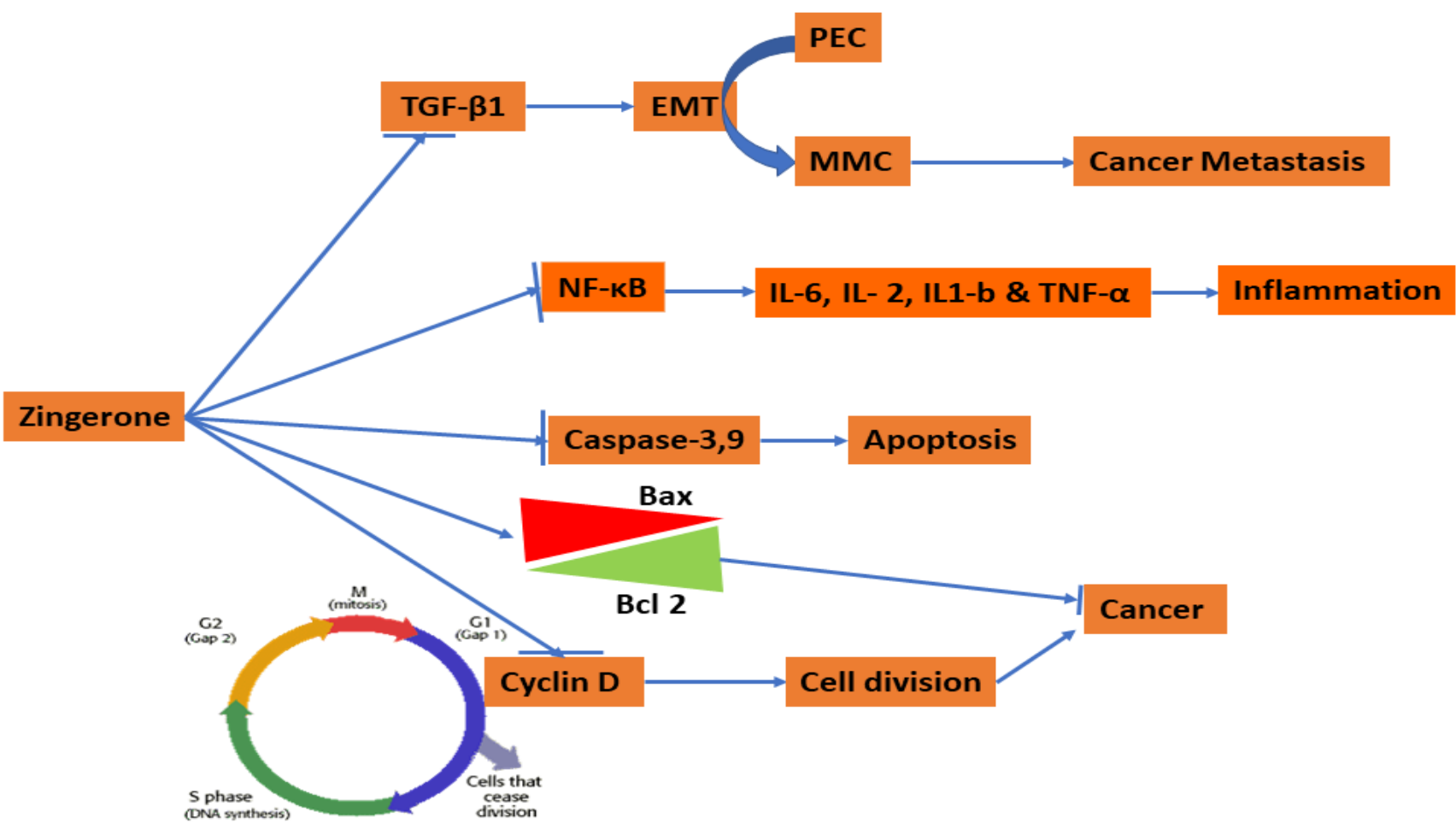

Fig. 4. Zingerone is involved in signalling pathways against various diseases.

Cancer metastasis is controlled by zingerone by inhibiting TGF- $\beta 1$. EMT is controlled by TGF- $\beta 1$ and is responsible for converting PEC to MMC, which further lead to cancer metastasis. Zingerone regulates NF-kB signalling in inflammation. Apoptosis and cancer are also regulated by zingerone. Zingerone induce Bcl 2 expression and supress Bax expression to inhibit cancer. Cell cycle check point protein complexes are inhibited by zingerone during cancer development. TGF- $\beta 1$ (Transforming growth factor-beta 1), EMT (Epithelial mesenchymal transition), PEC (Polarized epithelial cells), MMC (Motile mesenchymal cells), NF-kB (Nuclear factor kappa beta), IL (Interleukin), TNF (Tumor necrosis factor).

phosphate (NADPH) oxidase 4 (NOX 4) is upregulated by zingerone to prevent diabetic nephropathy (46).

\section{Other biological activities}

In a report of 2015, it was found that about 15.9 million of people suffers from myocardial infarction (47). The pretreated rats with zingerone showed prevention mechanism against isoproterenol induced myocardial infarction. This result concludes that zingerone is effective to protect heart from myocardial infarction disease $(48,49)$. The apoptosis responsive genes like Fas-receptor, caspase- 8 , caspase- 9 and caspase- 3 are found down regulated due to zingerone in myocardial infarction. $\mathrm{BCl}-2$ and $\mathrm{BCl}-\mathrm{xL}$ are upregulated whereas Bax and Bad genes are down regulated in zingerone treated myocardial infarction tissue (induced by isoproterenol) (50). Zingerone also decreases biofilm formation and subsequently enhances ciprofloxacin activity in Pseudomonas aeruginosa (43).

Osteoblast differentiation is the process leading to fibrinogen to fibrin. In addition to fibrin deposition, Platelets activated and aggregated to clot blood. But zingerone inhibits FXa formation and platelet aggregation (22).

\section{Conclusion}

Zingerone is used against diseases like myocardial infarction, hepatic cancer, colon cancer, neurological disorders and many other diseases. It has many important pharmacological activities like antioxidant, anticancer, antiinflammation, antithrombotic and various other activities. Zingerone is also found to regulate important genes like TGF- $\beta$, NF-kB, TNF- $\alpha$ and cytokines like interleukins in the signalling pathway. But the actual mechanism involved is still unknown. Extensive studies are required to elucidate the exact mechanism of this compound in various disease responses. More studies can be also focused on the biological activities of zingerone after cooking in comparison to its crude form. This review will further help in potential drug discoveries 
from ginger plant using zingerone. However, the contributions of zingerone to the pharma as well as medicinal industries can be very high for multiple therapies. In addition, this compound in nanoform showed effective activities than its crude form. As so many studies on its dietary supplements for various pharmacological activities have been reported, it can be adopted by pharma companies to develop novel drug molecules. The multiple bioactivities of zingerone will also further definitely help scientific communities to get depth knowledge on it and its importance in various health sectors.

\section{Author's contribution}

BCS did the literature survey and wrote the manuscript. SS helped in reviewing and editing the manuscript. SN helped in reviewing and editing the manuscript. BK gave the concept, designed the work, reviewed and edited the manuscript.

\section{Acknowledgements}

Authors are very much thankful to the president of Siksha ' $O$ ' Anusandhan deemed to be university, India for providing necessary facilities to carry out the above work. .

\section{Compliance with ethical standards}

Conflict of interest: The authors declare that they have no conflict of interest.

Ethical issues: None.

\section{References}

1. Dhanik J, Arya N, N and V, Jyotsna Dhanik C. A Review on Zingiber officinale J Pharmacogn Phytochem 2017;6:174-84.

2. Zhang YX, Li JS, Chen LH, Peng WW, Cai BC. Simultaneous determination of five gingerols in raw and processed ginger by HPLC. Chinese Pharm J. 2012;47:471-74.

3. Mbaveng AT, Kuete V. Zingiber officinale In: Medicinal Spices and Vegetables from Africa: Therapeutic Potential Against Metabolic, Inflammatory, Infectious and Systemic Diseases. 2017:627-39. https://doi.org/10.1016/B978-0-12-809286-6.00030-3

4. Habsah M, Amran M, Mackeen MM, Lajis NH, Kikuzaki H, Nakatani N, Rahman AA, Ghafar, Ali AM. Screening of Zingiberaceae extracts for antimicrobial and antioxidant activities. J Ethnopharmacol. 2000;72:403-10. https://doi.org/10.1016/s0378-8741(00) 00223-3

5. Jakribettu RP, Boloor R, Bhat HP, Thaliath A, Haniadka R, Rai MP, George T, Baliga MS. Ginger (Zingiber officinale Rosc.) Oils. In. Essential Oils in Food Preservation, Flavor and Safety. 2016;44754. Academic Press. https://doi.org/10.1016/B978-0-12-4166417.00050-X

6. Sacchetti G, Maietti S, Muzzoli M, Scaglianti M, Manfredini S, Radice $M$ et al. Comparative evaluation of 11 essential oils of different origin as functional antioxidants, antiradicals and antimicrobials in foods. Food Chem. 2005;91:621-32. https:// doi.org/10.1016/j.foodchem.2004.06.031

7. Tan KH. Fruit fly pests as pollinators of wild orchids. Orchid Digest. 2009 Sep;73(3):180-87.

8. Tan $\mathrm{KH}$, Nishida R. Zingerone in the floral synomone of
Bulbophyllum baileyi Orchidaceae) attracts Bactrocera fruit flies during pollination. Biochemical Systematics and Ecology. 2007 Jun 1;35(6):334-41. https://doi.org/10.1016/j.bse.2007.01.013

9. Furia TE, Bellanca N, (eds). Fenaroli's handbook of flavor ingredients. CRC Press Inc1975;Vol. 2.

10. National Center for Biotechnology Information. PubChem Database. Zingerone, $C I D=31211$ (accessed on July 3, 2019). https:// pubchem.ncbi.nlm.nih.gov/compound/Zingerone.

11. Supardan MD, Fuadi A, Alam PN, Arpi N. Solvent extraction of ginger oleoresin using ultrasound. Makara Journal of Science. 2012 Sep 7:163-67. https://doi/org/10.7454/mss.v15i2.1066

12. Xiong H, Liu S, Xiang W, Ma L. Optimization of the supercritical carbon dioxide fluid extraction process of zingerone in Zingiber officinale Rosc. Medicinal Plant. 2011;2(1):60-62. https:// doi.org/10.1016/j.supflu.2016.05.035

13. Smith LR. Rheosmin ("raspberry ketone") and zingerone and their preparation by crossed aldol-catalytic hydrogenation sequences. The Chemical Educator. 1996 Aug 1;1(3):1-8. https:// doi.org/10.1007/s00897960034a

14. Pranowo D, Raharjo TJ. Synthesis of Zingerone Using NiCl2• $6 \mathrm{H} 2 \mathrm{O}-\mathrm{NaBH} 4$ as a Selective Hydrogenation Reaction Agent. In Materials Science Forum 2019 (Vol. 948, pp. 127-32). Trans Tech Publications. https://doi.org/10.4028/www.scientific.net/ MSF.948.127

15. Manjunatha JR, Bettadaiah BK, Negi PS, Srinivas P. Synthesis of quinoline derivatives of tetrahydrocurcumin and zingerone and evaluation of their antioxidant and antibacterial attributes. Food chemistry. 2013 Jan 15;136(2):650-68. https://doi.org/10.1016/ j.foodchem.2012.08.052

16. Global Burden of Disease Collaborative Network. Global Burden of Disease Study 2017 (GBD 2017) Results. Seattle, United States: Institute for Health Metrics and Evaluation (IHME), 2018.

17. Ahmad B, Rehman MU, Amin I, Rasool S, Bhat SA, Afzal I, et al. A Review on Pharmacological Properties of Zingerone (4-(4Hydroxy-3-methoxyphenyl)-2-butanone). Sci World J. 2015. https://doi.org/10.1155/2015/816364

18. Kim YJ, Jeon Y, Kim T, Lim WC, Ham J, Park YN et al. Combined treatment with zingerone and its novel derivative synergistically inhibits TGF- $\beta 1$ induced epithelial-mesenchymal transition, migration and invasion of human hepatocellular carcinoma cells. Bioorg Med Chem Lett. 2017;27:1081-88. https://doi.org/10.1016/ j.bmcl.2016.12.042

19. Mani V, Arivalagan S, Siddique Al, Namasivayam N. Antioxidant and anti-inflammatory role of zingerone in ethanol-induced hepatotoxicity. Mol Cell Biochem. 2016;421:169-81. https:// doi.org/10.1007/s11010-016-2798-7

20. Bae WY, Choi JS, Kim JE, Park C, Jeong JW. Zingerone suppresses angiogenesis via inhibition of matrix metalloproteinases during tumor development. Oncotarget. 2016; 7:47232-41. https:// doi.org/10.18632/oncotarget.10030

21. Ahmad B, Rehman MU, Amin I, Ahmad SB, Farooq A, Muzamil S et al. Zingerone (4-(4-hydroxy-3-methylphenyl) butan-2-one) protects against alloxan-induced diabetes via alleviation of oxidative stress and inflammation: Probable role of NF-kB activation. Saudi Pharm J. 2018;26:1137-45. https://doi.org/10.1016/ j.jsps.2018.07.001

22. Lee W, Ku SK, Kim MA, Bae JS. Anti-factor Xa activities of zingerone with anti-platelet aggregation activity. Food Chem Toxicol. 2017;105:186-93. https://doi.org/10.1016/ j.fct.2017.04.012

23. Ganaie MA, Al Saeedan A, Madhkali H, Jan BL, Khatlani T, Sheikh IA et al. Chemopreventive efficacy zingerone (4-[4-hydroxy-3methylphenyl] butan-2-one) in experimental colon carcinogenesis in Wistar rats. Environ Toxicol. 2019;34:610-25. https:// doi.org/10.1002/tox.22727 
24. Choi JS, Ryu J, Bae WY, Park A, Nam S, Kim JE et al. Zingerone suppresses tumor development through decreasing cyclin D1 expression and inducing mitotic arrest. Int J Mol Sci. 2018;19:2832. https://doi.org/10.3390/ijms19092832

25. Vinothkumar R, Vinothkumar R, Sudha M, Nalini N. Chemopreventive effect of zingerone against colon carcinogenesis induced by 1,2-dimethylhydrazine in rats. Eur J Cancer Prev. 2014;23:36171. https://doi.org/10.1097/CEJ.0b013e32836473ac

26. Kung ML, Lin PY, Huang ST, Tai MH, Hsieh SL, Wu CC et al. Zingerone nanotetramer strengthened the polypharmacological efficacy of zingerone on human hepatoma cell lines. ACS Appl Mater Interfaces. 2019;11:137-50. https://doi.org/10.1021/ acsami.8b14559

27. Alrawi SJ, Schiff M, Carroll RE, Dayton M, Gibbs JF, Kulavlat M, Tan D, Berman K, Stoler DL, Anderson GR. Aberrant crypt foci. Anticancer Research. 2006 Jan 1;26(1A):107-19.

28. Mittler R. ROS are good. Trends in Plant Science. 2017 Jan 1;22 (1):11-19. https://doi.org/10.1016/j.tplants.2016.08.002

29. Rao BN, Rao BSS. Antagonistic effects of Zingerone, a phenolic alkanone against radiation-induced cytotoxicity, genotoxicity, apoptosis and oxidative stress in Chinese hamster lung fibroblast cells growing in vitro. Mutagenesis. 2010;25:577-87. https:// doi.org/10.1093/mutage/geq043

30. Ahmad B, Rehman MU, Amin I, Ahmad SB, Farooq A, Muzamil S et al. Zingerone (4-(4-hydroxy-3-methylphenyl) butan-2-one) protects against alloxan-induced diabetes via alleviation of oxidative stress and inflammation: Probable role of NF-kB activation. Saudi Pharm J. 2018;26:1137-45. https://doi.org/10.1016/ j.jsps.2018.07.001

31. Rao BN, Archana PR, Aithal BK, Rao BSS. Protective effect of zingerone, a dietary compound against radiation induced genetic damage and apoptosis in human lymphocytes. Eur J Pharmacol. 2011;657:59-66. https://doi.org/10.1016/j.ejphar.2011.02.002

32. Vaibhav K, Shrivastava P, Tabassum R, Khan A, Javed H, Ahmed $M E$ et al. Delayed administration of zingerone mitigates the behavioral and histological alteration via repression of oxidative stress and intrinsic programmed cell death in focal transient ischemic rats. Pharmacol Biochem Behav. 2013;113:53-62. https://doi.org/10.1016/j.pbb.2013.10.008

33. Alibakhshi T, Khodayar MJ, Khorsandi L, Rashno M, Zeidooni L. Protective effects of zingerone on oxidative stress and inflammation in cisplatin-induced rat nephrotoxicity. Biomed Pharmacother. 2018;105:225-32. https://doi.org/10.1016/ j.biopha.2018.05.085

34. Rajan I, Narayanan N, Rabindran R, Jayasree PR, Kumar PM. Zingerone protects against stannous chloride-induced and hydrogen peroxide-induced oxidative DNA damage in vitro. Biol Trace Elem Res. 2013;155:455-59. https://doi.org/10.1007/s12011 $-013-9801-x$

35. Rehman MU, Rashid SM, Rasool S, Shakeel S, Ahmad B, Ahmad $\mathrm{SB}$ et al. Zingerone (4-(4-hydroxy-3-methylphenyl)butan-2-one) ameliorates renal function via controlling oxidative burst and inflammation in experimental diabetic nephropathy. Arch Physiol Biochem. 2019;125:201-09. https:// doi.org/10.1080/13813455.2018.1448422

36. Lee J, Oh SW, Shin SW, Lee KW, Cho JY, Lee J. Zingerone protects keratinocyte stem cells from UVB-induced damage. Chem Biol Interact. 2018;279:27-33. https://doi.org/10.1016/ j.cbi.2017.11.004

37. Strickland I, Rhodes LE, Flanagan BF, Friedmann PS. TNF-alpha and IL-8 are upregulated in the epidermis of normal human skin after UVB exposure: correlation with neutrophil accumulation and E-selectin expression. J Invest Dermatol. 1997;108:763-68. https://doi.org/10.1111/1523-1747.ep12292156
Bruijnzeel PL. Pathophysiology of photoaging of human skin: focus on neutrophils. Photochem Photobiol Sci. 2006;5:184-89. https://doi.org/10.1039/b502522b

39. Bashir MM, Sharma MR, Werth VP. UVB and proinflammatory cytokines synergistically activate TNF-alpha production in keratinocytes through enhanced gene transcription. J Invest Dermatol. 2009;129:994-1001. https://doi.org/10.1038/ jid.2008.332

40. Hsiang CY, Cheng HM, Lo HY, Li CC, Chou PC, Lee YC et al. Ginger and Zingerone Ameliorate Lipopolysaccharide-Induced Acute Systemic Inflammation in Mice, Assessed by Nuclear Factor-kB Bioluminescent Imaging. J Agric Food Chem. 2015;63:6051-58. https://doi.org/10.1021/acs.jafc.5b01801

41. Taniguchi K, Karin M. NF-KB, inflammation, immunity and cancer: coming of age. Nat Rev Immunol. 2018;18:309-24. https:// doi.org/10.1038/nri.2017.142

42. Hsiang CY, Lo HY, Huang HC, Li CC, Wu SL, Ho TY. Ginger extract and zingerone ameliorated trinitrobenzene sulphonic acidinduced colitis in mice via modulation of nuclear factor-kB activity and interleukin-1 $\beta$ signalling pathway. Food Chem. 2013;136:170-77.

j.foodchem.2012.07.124

43. Kumar L, Chhibber S, Harjai K. Zingerone suppresses liver inflammation induced by antibiotic mediated endotoxemia through down regulating hepatic mRNA expression of inflammatory markers in Pseudomonas aeruginosa peritonitis mouse model. PLoS One. 2014;9:e106536. https://doi.org/10.1371/ journal.pone.0106536

44. Chung SW, Kim MK, Chung JH, Kim DH, Choi JS, Anton S et al. Peroxisome proliferator-activated receptor activation by a shortterm feeding of zingerone in aged rats. J Med Food. 2009;12:34550. https://doi.org/10.1089/jmf.2007.0660

45. Mani V, Arivalagan S, Islam Siddique A, Namasivayam N. Antihyperlipidemic and antiapoptotic potential of zingerone on alcohol induced hepatotoxicity in experimental rats. Chem Biol Interact. 2017;272:197-206. https://doi.org/10.1016/j.cbi.2017.04.019

46. Cui Y, Shi Y, Bao Y, Wang S, Hua Q, Liu Y. Zingerone attenuates diabetic nephropathy through inhibition of nicotinamide adenine dinucleotide phosphate oxidase 4. Biomed Pharmacother. 2018;99:422-30. https://doi.org/10.1016/j.biopha.2018.01.051

47. GBD 2015 Disease Injury Incidence Prevalence Collaborators. "Global, regional and national incidence, prevalence and years lived with disability for 310 diseases and injuries, 1990-2015: a systematic analysis for the Global Burden of Disease Study 2015". Lancet. 2015;388(10053):1545-602. https:// dx.doi.org/10.1016/S0140-6736(16)31678-6

48. Hemalatha KL, Prince PSM. Preventive effects of zingerone on altered lipid peroxides and nonenzymatic antioxidants in the circulation of isoproterenol-induced myocardial infarcted rats. J Biochem Mol Toxicol. 2015;29:63-69. https://doi.org/10.1002/ jbt.21668

49. Hemalatha KL, Prince PSM. A biochemical and 2, 3, 5-triphenyl tetrazolium chloride staining study on the preventive effects of zingerone (vanillyl acetone) in experimentally induced myocardial infarcted rats. Eur J Pharmacol. 2015;746:198-205. https:// doi.org/10.1016/j.ejphar.2014.10.057

50. Prince PSM, Hemalatha KL. A molecular mechanism on the antiapoptotic effects of zingerone in isoproterenol induced myocardial infarcted rats. Eur J Pharmacol. 2018;821:105-11. https:// doi.org/10.1016/j.ejphar.2017.09.051

51. Srinaath N, Balagangadharan K, Pooja V, Paarkavi U, Trishla A, Selvamurugan N. Osteogenic potential of zingerone, a phenolic compound in mouse mesenchymal stem cells. Biofactors. 2019. https://doi.org/10.1002/biof.1515

38. Rijken F, Kiekens RCM, van den Worm E, Lee PL, van Weelden H, 52. Sistani Karampour N, Arzi A, Rezaie A, Pashmforoosh M, Kordi F. 
Gastroprotective effect of zingerone on ethanol-induced gastric ulcers in rats. Medicina (Kaunas). 2019;55:64. https:// doi.org/10.3390/medicina55030064

53. Narayanan JM, Jesudoss VA. Hepatoprotective potential of zingerone against nonalcoholic fatty liver disease in rats fed with fructose-enriched diet. Gen Physiol Biophys. 2016;35:185-94 https://doi.org/10.4149/gpb_2015041

54. Cheong KO, Shin DS, Bak J, Lee C, Kim KW, Je NK et al. Hepatoprotective effects of zingerone on carbon tetrachloride and dimethylnitrosamine-induced liver injuries in rats. Arch Pharm Res. 2016;39:279-91. https://doi.org/10.1007/s12272-015-0696-2
55. Soliman AF, Anees LM, Ibrahim DM. Cardioprotective effect of zingerone against oxidative stress, inflammation and apoptosis induced by cisplatin or gamma radiation in rats. Naunyn Schmiedebergs Arch Pharmacol. 2018;391:819-32. https:// doi.org/10.1007/s00210-018-1506-4

$\S \S \S$ 